\title{
An Examination of How Households Share and Coordinate the Completion of Errands
}

\author{
Timothy Sohn, Lorikeet L. Lee ${ }^{2}$, Stephanie M. Zhang ${ }^{2}$, David Dearman ${ }^{2,3}$, Khai N. Truong ${ }^{2}$ \\ ${ }^{1}$ Google Inc. \\ 1600 Amphitheatre Parkway \\ Mountain View, CA 94043 USA \\ ${ }^{2}$ Department of Computer Science \\ University of Toronto \\ Toronto, ON M5S 3G4 Canada \\ ${ }^{3}$ Nokia Research Center \\ 955 Page Mill Rd. \\ Palo Alto, CA 94304 USA
}

\begin{abstract}
People often complete tasks and to-dos not only for themselves but also for others in their household. In this work, we examine how household members share and accomplish errands both individually and together. We conducted a three-week diary study with eight households to understand the types of errands that family members and roommates share with each other. We explore their motivations for offering and requesting help to complete their errands and the variety of methods for doing so. Our findings reveal when participants sometimes face challenges completing their errands, and how household members request and receive help. We learned that the cooperative performance of errands is typically dependent on household members' location, availability, and capability. Using these findings, we discuss design opportunities for cooperative errands sharing systems that can assist households.
\end{abstract}

\section{Author Keywords}

cooperative errands, families, roommates, coordination

\section{ACM Classification Keywords}

H5.m. Information interfaces and presentation (e.g., $\mathrm{HCI}$ ): Miscellaneous.

\section{General Terms}

Design, Human Factors.

\section{INTRODUCTION}

People have a variety of tasks and to-do items that they must accomplish for themselves. Many of these tasks, called errands, require people to make trips outside of their home to complete. Errands often consume a non-trivial amount of time to complete because of the time it takes to travel to and from the locations where the tasks need to be performed, as well as the time and effort that it takes to complete the tasks themselves. As a result, Americans spend on average over 2.5 hours each day at locations

Permission to make digital or hard copies of all or part of this work for personal or classroom use is granted without fee provided that copies are not made or distributed for profit or commercial advantage and that copies bear this notice and the full citation on the first page. To copy otherwise, or republish, to post on servers or to redistribute to lists, requires prior specific permission and/or a fee.

CSCW'12, February 11-15, 2012, Seattle, Washington, USA.

Copyright 2012 ACM 978-1-4503-1086-4/12/02 ...\$10.00. outside of their homes [19] to perform a variety of instrumental activities of daily living (e.g., grocery shopping, automobile maintenance).

Those who live with family members or roommates can offer to help other household members complete their errands or ask for help completing their own. For example, a college student who forgot his project report on his desk at home could ask a roommate, who has yet to leave home, to bring the report to class with him. Similarly, a wife may offer to pick up some ice on her way home so that her husband can continue with other preparations for their dinner party at their home later that evening. The availability and assistance of household members can reduce the amount of time needed to perform an errand and allow households to cooperatively perform household tasks.

Although several studies have explored individual task management and family coordination habits [8, 29, 33], few have explored the methods used by households to specifically address errands. What motivates household members to ask for help? What situations influence decisions whether to help with an errand? Understanding how households (i.e., families or roommates) perform errands can provide insights to improve household coordination in cooperatively accomplishing their errands.

In this work, we examine how household members share and accomplish tasks both individually and together. Due to the communal aspect of approaching errands, we refer to errands shared within a household as cooperative errands. We conducted a three-week diary study with eight households to examine the types of errands that family members and roommates share with each other, their motivations for offering and requesting help to complete their errands, and the methods for doing so. Our findings reveal that participants sometimes face challenges in completing errands due to time, location, and circumstances. The urgency of an errand and the resources of other household members are two of the primary factors that influence the sharing of errands amongst a household. Household members were generally willing to help others, but sometimes faced barriers due to not knowing each others' errands or the potential helpers' whereabouts and availability to help with errands. Based on our observations and interviews with participants, we discovered several design opportunities to enhance cooperative errand sharing 
systems that could improve the communication and coordination of errands within households of both families and roommates. The following sections describe our study methodology, results, and the design opportunities to support cooperative errands.

\section{RELATED WORK}

Errands are to-do tasks that require people to make a trip to accomplish. The focus of this work is on how households share and coordinate the completion of errands, which is closely related to task management and reminder systems, and family coordination systems. In a group setting, individuals can share tasks and take advantage of situations where one individual may be better situated to accomplish a task. We first provide a review of previous research that has focused on individual task management, then review previous research that has focused on family coordination of domestic activities.

\section{Task Management \& Reminder Systems}

Early task management research has examined the artifacts and processes that people use to manage information (such as meetings, contacts, documents) to accomplish their work [20]. These task management systems have focused on tasks typically executed on a desktop workstation to support workplace task management $[2,3,5,7,8]$.

Although workplace task management is an important domain, many everyday tasks require support away from the desktop [5, 22]. Ludford et al. demonstrate that although people pre-plan and create information resources to perform everyday tasks, a location-based reminder system is useful in helping users spatially organize their tasks [22]. Locationbased reminder systems provide a contextual method to trigger a reminder at a specified location [14, 17, 18, 22, 23, $27,29]$. These systems allow the user to input a note that is triggered based on her presence at a location. Sohn et al. reported that participants in their study used such a system $30 \%$ of the time to inform them to make trips and to bring or get items from different locations (i.e., reminders for errands) [29]. These studies have focused primarily only on the user's personal tasks but not those belonging to others, such as those in the user's household.

\section{Family Coordination Systems}

Research about how domestic technologies can be built to support family coordination has focused on patterns of interaction within the home [11], and how these interactions relate to everyday artifacts $[31,34]$ and routines $[1,12,16]$. At the heart of family life is the mutual awareness that household members have of each other's locations and activities throughout each day. This awareness can be gained through location sharing [4, 8] and group calendar systems $[25,10]$. Knowing the schedule and whereabouts of other family members can assist in coordinating tasks. However, family calendars can deviate from reported schedules, and in these cases family members often rely on routines that are implicitly communicated and understood amongst family members [12].
In order to address schedule changes and assist in spontaneous family communication, some households coordinate using messaging systems. Taylor et al. showed that notes attached to the refrigerator make the fridge's location a significant place for supporting task organization, planning and reminding [32]. Electronic versions of coordination systems can help support family communication and coordination within the home [21, 24] as well as remotely [28]. For example, the TxtBoard system supports family coordination by enabling household members to send text messages to the home that are then shown on an electronic display [26]. Elliot et al. leverage user location and context to help people better understand and manage their information and tasks within the home; they demonstrate how to deliver messages at meaningful times and locations based on knowledge of their routines [15].

In this paper, we extend previous research by exploring how errands are communicated and coordinated within households. The key distinction in our work is that we examine the errand sharing practices of families and roommates who cohabitate. Although families have many different kinds of lists that they maintain and create [33], in this work we focus specifically on errands-tasks that require a person to make a trip to accomplish. Further, our work studies also the practices of those who live together as roommates, and not only families.

\section{METHOD}

We conducted a three-week diary study to explore the errands that eight different households performed. Diary studies enable us to gather ecologically valid data from participants because they can document an errand when it starts and ends, with minimal disruption to normal activities.

\section{Participants}

We recruited eight households (three families, five households shared by roommates) through word-of-mouth and flyers posted in two North American cities. Participation was open to any household with at least three people ages 16 or older who lived together. We used 16 years of age as the lower bound for participation to include families with teenage children who could potentially perform errands on their own. We did not enforce any other restrictions because we wanted to ensure a diverse participant sampling with respect to background and daily experiences given the broad nature of our exploration. The age of our participants ranged from 18-55 with a variety of occupations. In three households (H5, H6, and H7), only individuals who were present in the home during the study and actively contributed to performing errands participated in the study. For example, the $\mathrm{H} 7$ household has two children who were younger than 10 years old; they were excluded from the interviews because they did not actively contribute to the performance of errands. Details about the participants can be found in Table 1 .

\section{Procedure}

We instructed participants to keep a diary of their daily errands (Figure 1) for a period of three weeks. We defined 
an errand as a short and quick trip to accomplish a specific purpose, as to buy something, deliver a package, or convey a message; or a short trip undertaken to perform a necessary task or commission. However, we encouraged participants to enter any task into the diary that they perceived as an errand and allow us to determine if it met our definition. Participants were instructed to write down errands as they thought of them, including errands they did not complete, errands they asked others within and outside of their household to help perform, and errands they were asked by others to help perform.

We met with participants weekly to collect the diaries, interview them, and give them new diaries for the next week if needed. Interviews took between 15-60 minutes and followed a semi-structured format, allowing the interviewer to probe further about each diary entry. We asked the participants to explain the intent for each of their errands in greater detail when applicable. If the errand was completed, we asked how it was completed and by whom; alternatively, for errands that were not completed, we probed why they had not been completed. For errands which they were asked by others to help with or ones which they asked others to help perform, we also probed about whom the other the persons were and why they were asked. At the end of the final week, we conducted an exit interview with each household to understand their overall experiences, asking them to reflect on the current practices their household uses to communicate and coordinate errands. Participants discussed several possible design ideas to address many of the barriers faced in the coordination of errands. The weekly and exit interviews were all audio recorded with participant consent for analysis.

We compensated households composed of roommates $\$ 50$ for the first week, $\$ 75$ for the second week, and $\$ 100$ for the final week ( $\$ 225$ total). Households composed of family members were compensated $\$ 75$ for the first week, $\$ 125$ for the second week, and $\$ 200$ for the last week ( $\$ 400$ total). Because we experienced great difficulty recruiting families, they were compensated a higher amount. All households were also entered into a drawing for one of two Microsoft Xbox 360 consoles with Kinect (valued at \$299).

\section{Instrument}

We designed the diary as a small pocketsize paper journal that participants can carry to make full or partial entries in situ [13] as errands were started and completed. Each page of the

\begin{tabular}{|c|c|c|c|c|c|c|}
\hline \multirow[t]{2}{*}{ Household Code } & \multirow[t]{2}{*}{ Participants } & \multirow{2}{*}{$\begin{array}{l}\text { Common Errands Performed } \\
\text { Top } 3 \text { errands during the study }\end{array}$} & \multicolumn{4}{|c|}{ Errands per Week } \\
\hline & & & Completed & Uncompleted & $\begin{array}{l}\text { Asked others } \\
\text { to help }\end{array}$ & $\begin{array}{l}\text { Asked by others } \\
\text { to help }\end{array}$ \\
\hline \multirow[t]{3}{*}{ H1 - Roommates } & A - Female; 18-25; Clinical Research Assistant & $\begin{array}{l}\text { Buy/sell, gifting, returning items, } \\
\text { transporting }\end{array}$ & $3.7, \sigma=2.5$ & $1, \sigma=0.8$ & $1.3, \sigma=1.2$ & $2, \sigma=1.6$ \\
\hline & B - Female; 26-35; student/teacher & Buy/sell, transporting, gifting & $5, \sigma=5.7$ & $1, \sigma=0.8$ & $1.3, \sigma=1.9$ & $4.3, \sigma=4.8$ \\
\hline & C - Female; 26-35; temp & $\begin{array}{l}\text { Finance-related, transporting, } \\
\text { returning items }\end{array}$ & $3.3, \sigma=4.7$ & & $2.7, \sigma=3.1$ & $0.7, \sigma=0.5$ \\
\hline \multirow[t]{3}{*}{ H2-Roommates } & A - Male; 18-25; undergraduate student & $\begin{array}{l}\text { School-related, planning, } \\
\text { transporting }\end{array}$ & $2, \sigma=1.4$ & $0.3, \sigma=0.5$ & $0.3, \sigma=0.5$ & $0.3, \sigma=0.5$ \\
\hline & B - Male; 18-25; undergraduate student & $\begin{array}{l}\text { Transporting, finance-related, } \\
\text { school-related, planning }\end{array}$ & $1, \sigma=0.8$ & $0.3, \sigma=0.5$ & $1, \sigma=0.8$ & \\
\hline & C - Male, 18-25; undergraduate student & Buy/sell, school-related & $1, \sigma=1.4$ & $0.3, \sigma=0.5$ & & $0.3, \sigma=0.5$ \\
\hline \multirow[t]{3}{*}{ H3-Roommates } & A - Male; $18-25 ;$ student & $\begin{array}{l}\text { Buy/sell, transporting, household } \\
\text { chores, school-related }\end{array}$ & $2.7, \sigma=0.9$ & & $0.7, \sigma=0.9$ & \\
\hline & B-Male; 18-25; student & $\begin{array}{l}\text { School-related, planning, } \\
\text { transporting }\end{array}$ & $0.7, \sigma=0.9$ & $0.3, \sigma=0.5$ & $0.3, \sigma=0.5$ & $0.7, \sigma=0.9$ \\
\hline & C-Male; $18-25 ;$ student & $\begin{array}{l}\text { School-related, transporting, } \\
\text { buy/sell }\end{array}$ & $0.7, \sigma=0.9$ & $0.7, \sigma=0.9$ & & $0.3, \sigma=0.5$ \\
\hline \multirow[t]{3}{*}{ H4-Roommates } & $\begin{array}{l}\text { A -Female; 26-35; Academic Program Assistant } \\
\text { at UCSC Extension }\end{array}$ & Buy/sell, transporting, gifting & $8.3, \sigma=4$ & & $0.7, \sigma=0.9$ & $4.3, \sigma=3.4$ \\
\hline & B - Female; 18-25; Certified Nurse's Aide & $\begin{array}{l}\text { Transporting, work-related, } \\
\text { maintenance }\end{array}$ & $6.3, \sigma=3.3$ & & & $1, \sigma=1.4$ \\
\hline & C - Female; $18-25$; student & $\begin{array}{l}\text { Buy/sell, returning items, } \\
\text { maintenance }\end{array}$ & $6, \sigma=2.4$ & & & $0.7, \sigma=0.9$ \\
\hline \multirow{3}{*}{$\begin{array}{l}\text { H5 - Roommates } \\
\text { [only roommates who were } \\
\text { present in the home during } \\
\text { the study participated] }\end{array}$} & A - Male; $18-25 ;$ student & Buy/sell, gifting, school-related & $1, \sigma=0.8$ & & & \\
\hline & B - Female; 18-25; student & Buy/sell, personal, work-related & $1.3, \sigma=1.9$ & & & \\
\hline & C - Male; 26-35; graduate student & Transporting, gifting, buy/sell & $2.3, \sigma=1.7$ & & & $0.3, \sigma=0.5$ \\
\hline \multirow{3}{*}{$\begin{array}{l}\text { H6 - Family } \\
\text { [only siblings who performed } \\
\text { errands participated in the } \\
\text { study] }\end{array}$} & A - Female; $18-25$; student & $\begin{array}{l}\text { Buy/sell, transporting, personal, } \\
\text { school-related, assistance }\end{array}$ & $2.7, \sigma=2.5$ & & $1.7, \sigma=1.7$ & $1.3, \sigma=1.9$ \\
\hline & B-Male; $18-25 ;$ unemployed & $\begin{array}{l}\text { Buy/sell, work-related, transporting } \\
\text { (more) }\end{array}$ & $2, \sigma=0.8$ & $0.3, \sigma=0.5$ & $1.3, \sigma=0.5$ & $1.7, \sigma=0.5$ \\
\hline & C-Female; $18-25$; student & Transporting, buy/sell, maintenance & $8, \sigma=3.3$ & & $1, \sigma=0$ & $8.7, \sigma=3.3$ \\
\hline \multirow{3}{*}{$\begin{array}{l}\text { H7 - Family } \\
\text { [only family members who } \\
\text { are older than } 16 \text { years of age } \\
\text { participated in the study] }\end{array}$} & A-Male; 18-25; student & Transporting, buy/sell, maintenance & $3, \sigma=2.2$ & & & $1.7, \sigma=1.2$ \\
\hline & B - Female; 46-55; stay at home mom & $\begin{array}{l}\text { Buy/sell, transporting, returning } \\
\text { items }\end{array}$ & $5, \sigma=0.8$ & $0.3, \sigma=0.5$ & $0.3, \sigma=0.5$ & $2.3, \sigma=0.9$ \\
\hline & C-Male; 36-45; press operator & $\begin{array}{l}\text { Transporting, assistance, personal } \\
\text { (more) }\end{array}$ & $2, \sigma=0.8$ & $0.3, \sigma=0.5$ & $0.3, \sigma=0.5$ & $1, \sigma=0.8$ \\
\hline \multirow[t]{3}{*}{ H8-Family } & A-Female; 55+; social services workers & Transporting, buy/sell, gifting & $5, \sigma=0.8$ & & $2, \sigma=1.4$ & \\
\hline & B - Male; $18-25 ;$ business systems analyst & Buy/sell, maintenance & $0.7, \sigma=0.5$ & & & $0.7, \sigma=0.9$ \\
\hline & C-Male; 55+; retired & $\begin{array}{l}\text { Gifting, maintenance, transporting, } \\
\text { finance-related }\end{array}$ & $1.3, \sigma=0.9$ & & & $1.3, \sigma=1.2$ \\
\hline
\end{tabular}

Table 1. Household \& errands overview. Table cells are blank if the participant did not report errands matching the specified criteria. 

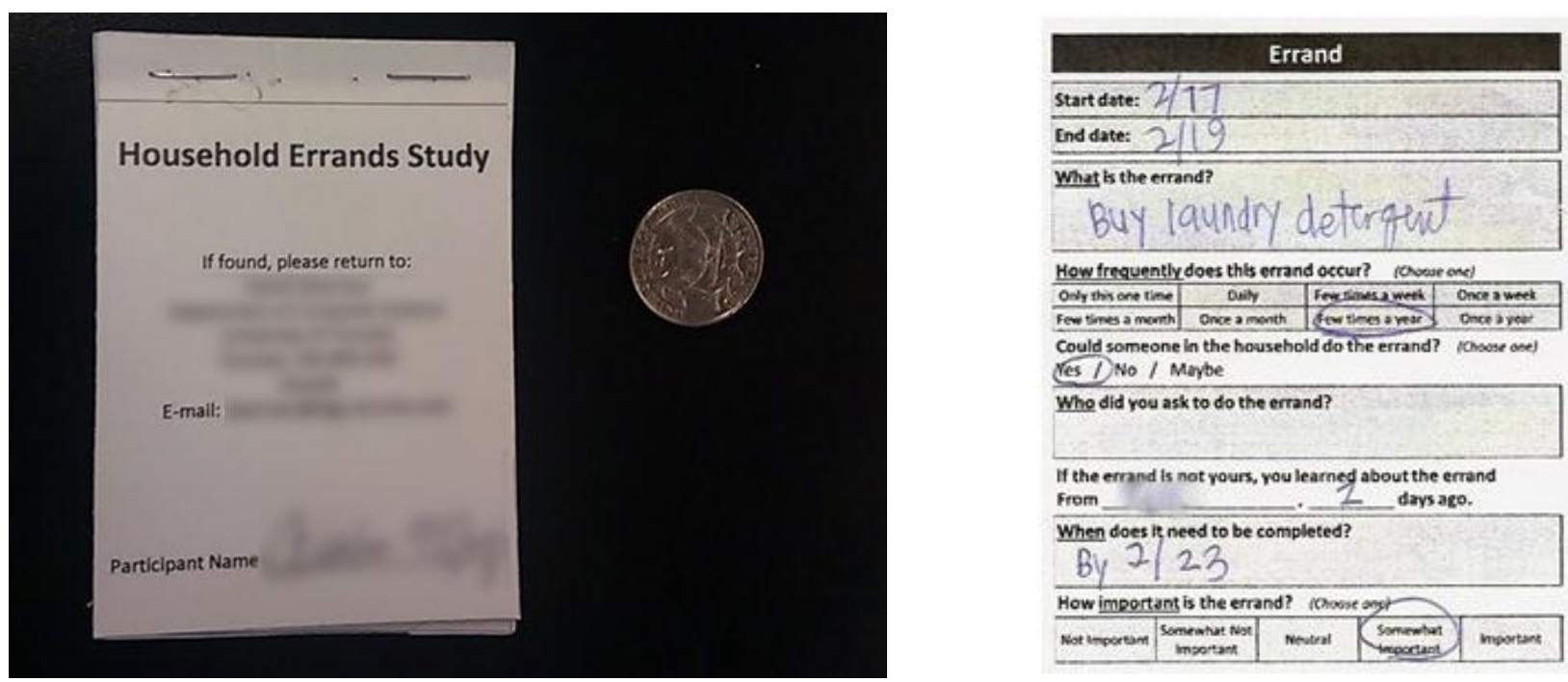

Figure 1. The diary form factor (left). An actual diary page completed about an errand (right).

diary contained a short structured form (Figure 1: right) with the following questions about the errand that the participant needed to perform or was asked to help perform by others:

- A description of the errand

- The date when it started being an active errand

- The date when it ended being an active errand

- The participant's perception of when the errand needed to be completed by

- How frequently that particular errand arises

- Who they might have asked to help with the errand

- If the errand was not their own, who asked them to help and when

- Their perception of the importance of the errand.

A diary study does have some limitations. Self-reported information may not be complete and may also contain inaccuracies. Additionally, participants may forget or choose not to report all qualifying entries. Our specific approach takes these limitations into consideration. To minimize any disturbances, we intentionally designed the diary to ask for very short and specific information to minimize the time burden when completing an entry. Additionally, we performed an interview with each household every week to elicit additional details. A diary study also allows participants to self-filter out sensitive experiences when necessary. At the very least, the number of diary entries gathered using this technique provides a realistic lower bound for the number of times participants experienced the studied effect. We thus chose to use a diary study because we thought it would be the most effective technique to capture data to reveal the nature of individual and cooperative errands.

\section{Analysis}

To analyze the errands, one researcher performed an affinity clustering [6] to identify and group similar entries. The affinity clustering was then challenged by the rest of the research team, followed by a round of refinement. The process of challenging and refining the clusters was repeated for 2 additional iterations until a final consensus was reached.

We identified the participants' motivations for cooperatively performing errands and their method for doing so by analyzing transcripts of the weekly interviews using open coding [30]. Three coders participated in the coding activity and discussed the data, forming and grouping codes, until agreement was reached.

\section{RESULTS AND DISCUSSION}

In this section, we describe the practices we observed among our participants in completing errands. We first present the errands reported by the participants. We then discuss why participants cooperatively performed errands and how they coordinated such efforts.

\section{Reported Errands}

Overall, participants recorded a total of 241 errands, with each household averaging 30 entries over the three weeks of the study. Participants indicated that they were able to complete 226 (93.8\%) errands and unable to complete 15 (6.2\%) errands. Each participant reported: performing 3.3 errands per week; asking others to help with 0.6 errands per week; being asked to help with 1.4 errands per week; and, not completing 0.2 errands per week.

We used affinity clustering to group the participants' errands into 11 categories (Table 2). The three types of errands most frequently recorded were buy/sell (96 entries), transporting (68 entries), and maintenance (20 entries). Participants most commonly asked for help when performing a transporting (21 entries) and buy/sell (10 entries) errand. These errands typically involve being mobile to move or purchase items. Many of the other categories are not as frequent (e.g., haircuts for personal errands) or are more difficult to ask another household member for help (e.g., work-related). 
The majority of errands the participants recorded occur infrequently or do not reoccur; the median frequency of an errand was 3 out of $8(M=2.9$, SD: 2.0$)$ where 1 is only this one time and 8 is daily. Only 3 entries were marked as daily errands and 31 entries were marked as weekly errands. In addition, participants reported their errands as important (median=5, $\mathrm{M}=4.3, \mathrm{SD}=1.0$ ) on a 5-point Likert scale; $1=$ not important and 5=important. The importance of an errand was generally interpreted based on the urgency of the errand, the number of opportunities to perform the errand, or how impactful the errand would be on their life (e.g., confer with immigration office about Canadian visa).

\section{H4-C: If there's no other time to [do the errand] then it'll seem more important.}

\section{Challenges with completing errands individually}

The participants faced numerous challenges that hindered their ability to complete errands individually. Our interviews revealed five reasons why errands were often not completed.

Often participants simply just forget about an errand. This frequently happened when participants perceived an errand to be low in priority and that it did not need to be completed immediately. The longer they delayed in addressing the errand, the less likely it was to be completed or forgotten.

\section{H3-A: I had to get a spare key made because I lost mine, but I haven't gotten it yet. I can just call myself and I buzz myself in our main door. I need to talk to my landlord because it is the magnetic key. So I haven't gotten to that yet this week. I just don't feel it's really necessary right now.}

Having a key to get into one's own house is very important, but because this participant had an alternative method for getting into this apartment, he perceived this errand as having low urgency. If he did not have this other method of entry, the urgency of the errand would have likely increased significantly. The urgency of an errand is also affected by its perceived deadline. For participant H2-C, school-related errands were important, but not necessarily urgent because the deadlines could be months away.

\section{H2-C: I didn't pick up all my textbooks... cause one of the midterms is in March so I didn't feel like I needed to pick it up right now.}

Participants expressed that the cost associated with attempting or performing an errand affects their ability to complete it. For example, participants sometimes delayed completing a task that involves spending a large amount of money for as long as possible. However, simply attempting an errand also involves time and effort, which sometimes participants are not willing to exert.

\section{H3-B: I would have to go to IKEA, but it's pretty far. I had planned to go there one day, but found out it was going to take 45 minutes [on bus]... and if we go there and it's closed then we messed up, because we would have spent close to an hour getting there [it would be like] we never went.}

Finally, even when participants have the time and desire to perform an errand, there are external factors that may prevent them from completing the task. For example, they may only be free at a time outside of a location's hours of operations or perhaps the weather does not permit them to complete the task.

H5-B: I've still yet to go to the bank. This is three weeks now. I was going to go today, but it's closed. It's a holiday. Because I don't have school this week, I have more time.

\section{Reasons for cooperatively performing errands}

Participants described numerous benefits from cooperatively performing errands. Participants gained personally from having help from other household members, but would also cooperatively perform errands due to communal and cultural reasons (e.g., oldest daughter performs most household errands).

\section{Benefits of completing errands cooperatively}

Sharing and communicating errands with other household members can help address some of the described challenges that participants faced completing errands individually. Cooperatively addressing errands can take advantage of other household members' time, knowledge, and abilities providing access to additional resources in order to complete errands.

One clear benefit to cooperatively performing errands is that people can help each other complete important tasks. The importance of an errand strongly influences a participant's decision to ask others to help with completing that task. The reasons why an errand is important can be multifaceted, strongly influencing how the errand will be prioritized.

H3-A: I think it works really well, especially when there are

\begin{tabular}{|l|l|l|l|}
\hline Category & Examples & $\begin{array}{l}\text { \# of Category } \\
\text { Entries }\end{array}$ & $\begin{array}{l}\text { Asked for } \\
\text { Help }\end{array}$ \\
\hline Buy/Sell & "Grocery shopping for a party." & 96 & 10 \\
\hline Transporting & "Pick up my friend's daughter." & 68 & 21 \\
\hline Maintenance & "Get gas for car." & 20 & 1 \\
\hline Finance-related & "Go to the bank to close an account." & 12 & 6 \\
\hline Personal & "Get a haircut" & 11 & 2 \\
\hline School-related & "Get book photocopied." & 8 & 2 \\
\hline Work-related & "Job interview." & 8 & 0 \\
\hline Planning & "Check out venue for an event." & 6 & \\
\hline Household Chores & "Get rid of Christmas tree." & 4 & 1 \\
\hline Assistance & "Accompany my wife to the store to take care of the kids while she shops." & 4 & 0 \\
\hline Gathering Data & "Take pictures of a house for my mom's insurance business." & 1 \\
\hline
\end{tabular}

Table 2. Errand categories. 
more than two people, because then you have a backup as well. Anything you have to do, if it is really necessary, then it's going to be done. So I think it's really, really helpful to live with someone who can help you out with your stuff.

Involving the help of others to complete errands helps get such tasks done more quickly and efficiently than if participants were to do it personally.

\section{H7-A: It's about functionality. Whichever way I can do it the fastest, I'll do. It's the same with her and my dad. Whoever can do it fastest within the group, we'll just send him or her.}

H7-B: The sooner we can do it, the better, so that it's out of our mind. Then we don't have to think about it.

If they have time and are able to help, participants were generally willing to help each other. For example, participant H4-C stated that her roommate, participant $\mathrm{H} 4-$ $\mathrm{B}$ had "the most flexible and predictable schedule, so she can run a lot of errands for us. " Household members were able to identify appropriate times to ask for help in performing errands and could rely on the availability of their other household member with more free time.

Often another person in the household has the knowledge and ability to help complete one's errands. As described earlier, perhaps their assistance may result in the completion of a task quicker than had the individual tried to complete it herself. A person might simply be located where they are able to help. Their physical ability to perform a task is sometimes the reason a person is asked to help. For example, some participants asked fellow household members to come along on shopping trips to help carry things that they would not be able to carry alone. Another person's assistance can also result in the task being completed better than if one were to attempt to perform it alone. Many times, participants asked for help when they lacked the skills or the expertise to perform the activity.

\section{H7-B: I don't know how to buy stuff for her music course, like the [strings] for her guitar, they break. I don't know how to buy them, so I call him. I don't know how to call them [sic] and so I don't know where to buy them.}

\section{Communal and cultural expectations for helping others}

A large percentage of the errands reported by the participants were not just their own tasks, but reflected activities that benefited the entire house. These communal factors made participants feel comfortable asking each other to help with such errands. Participants frequently assisted each other because of their desire to help as common courtesy. This was especially true when the other person was sick or extremely busy.

H3-B He got sick Thursday night, and he had an assignment due on Friday. Friday morning, he was up at like 8 in the morning and I could tell he was sick. And he asked, "Are you going to school today?" I said "Yeah." And he asked, "Could I get you to submit my assignment on your way?" I said "OK. Just put it on my desk and tell me where to take it."
H3-A: I think it's because we're all students. We really understand what the other person needs in terms of if someone asked me to do something, then I know that he really wants that thing to be done...otherwise he would really just do it himself.

Several households also described roles and cultural expectations as a reason why some members of their household helped to perform errands for others. Because of their culture, they assumed particular roles in the family. As a result, many of the errands became their responsibility to complete.

H6-A: My mom will say "Just do it, just do it."

H6-C: He is the eldest son. Even though I'm the oldest [child], my mom will always say "whatever that he says, just do it, no matter how lazy he's being. You're his sister, it's your job."

In another household, participant H4-A, who is the eldest daughter, would frequently travel home to "help with a lot of errands for the family." This included errands such as going to the grocery store, pharmacy, and other miscellaneous household tasks.

Although such expectations differ across different cultures, the notion of roles within a household is one that held true across several different groups of participants in our study. These roles can be defined based on where someone is typically located, as well as their skills and expertise, which we described earlier.

\section{Methods for Cooperatively Completing Errands}

In the previous section, we discussed the motivations for why participants cooperatively complete their errands. In this section, we discuss the methods that they use in order to be able to involve each other's help in completing their errands. These methods are not necessarily mutually exclusive and most households employed multiple methods during this study.

\section{Explicitly Coordinate Help}

Although they may each do so differently, all households reported some explicit coordination of how members of their household can help each other. Often one person in the house determines what needs to be done and informs those who can help to complete those tasks. In one instance, the coordinator is simply a person through whom information flows. This information can include what needs to be done, by whom, when and where.

\section{H6-A: We leave notes. It's mostly for my mom. If the note is for my dad, it's so that my mom can read the note and deliver the message to my dad.}

Another strategy used is to negotiate ahead of time how different members of the household can help to complete tasks that happen regularly.

\footnotetext{
H3-B: There's a Pakistani supermarket that's far away. So we go there once a month. We do the big grocery shopping there, like chicken and meat and stuff.

H3-C: Like in bulk...It's only once a month, so we're like ok, we can come and help carry stuff.
} 
H3-B: It can be anyone, one of them and me, the two of them... it's whoever is free that week, they can go. The thing is we need chicken and meat and stuff. So whenever that's finished, whenever we have time, we go as soon as possible.

\section{Offer Help Based on Location}

Although it did not happen as frequently as we expected, most participants discussed informing other household members when they are able to run errands at specific locations to see if they can help complete other tasks at the same time. Participants also sometimes contacted others in their household from locations where they think they might be able to help perform some errands. Participants offer their assistance because they want to remove the need for others to make an unnecessary trip.

\section{H6-C: Whenever I go out, I tend to call my mom and say, "Do you want anything while I'm here?" I always look out that way. I'm here, I spent \$3 to get here on the bus. I might as well make the most of it and see if there's anything someone else needs done so no one else needs to make the trip.}

\section{Request Help Based on Presumed Routine}

Participants frequently sought help with completing errands by using their knowledge of the other household members' routines. With an assumption of where others might be located and their activities, participants are able to determine who is possibly in position to be able to help them and ask them for assistance.

H3-A: It's just living together and getting to know each other. We're sort of familiar with each other's routines, so we would just know that...OK, so he would be at this guy's place at this time. I don't know how to explain it... it's just instinctual, I don't know.

H3-B: Right, so then the first thing I'd ask is "Hi, where are you?" And he'll say, "Blah, blah, blah." Then I'll ask, "Can you bring back this thing on your way back home?" And he'll say, "Sure."

Participants reported a willingness to help complete errands for others if they are asked in a situation that allowed them to do so.

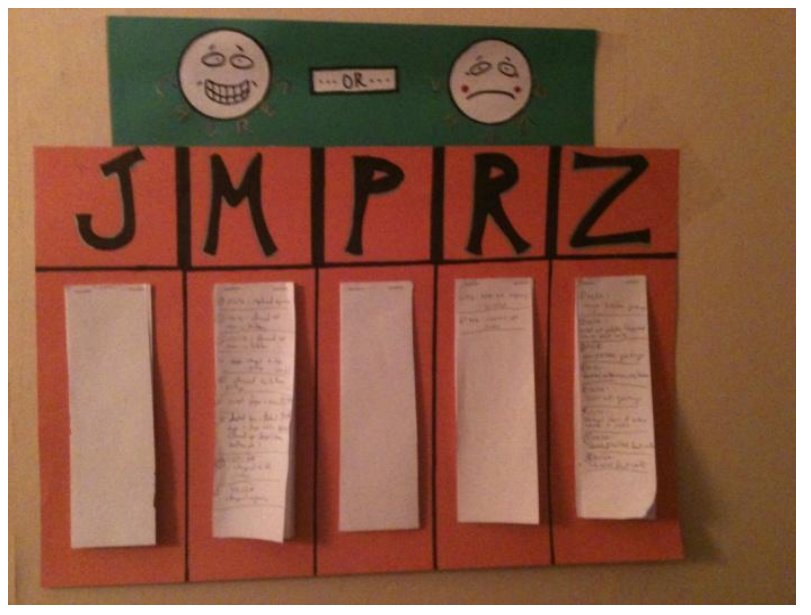

Figure 2. The "chore vs. shame" chart
H6-A: Yeah, I would help if that's something where I'm there. It would be inappropriate [sic] for me to say, "Come do it yourself." Right? So I would do it at that time.

Track Individual Contributions to the Household

Participants were generally aware of how much work different people performed to help complete household tasks. As part of being courteous of others, participants often would attempt to minimize how often they ask for favors from others until they have been able to reciprocate.

\section{H5-C: If I find that I've sort of have been using them more than they've been using me, to put it crudely, then I'm less likely to ask them for a favor until I feel like order has been restored.}

One group of roommates leveraged the fact that people within a household will feel compelled to contribute more when they are aware of the amount of work others have performed. They maintained a chart (Figure 2) on which each member of the household can write down the tasks that he or she has recently completed which benefits the group. The purpose of the chart was to make each other more explicitly aware of the amount of work that the different household members have each performed recently.

\section{H5-A: It's called the "chore vs. shame chart." We just hope that it'll put it in everyone's face how much everyone is doing so that they can be like, "Oh crap! So and so has done eight chores and I've only done two" and take more initiative.}

In being able to see how much work each person within the household has contributed recently and who was the last person to perform a particular task, work is implicitly assigned to that person without much further explicit coordination.

\section{H5-A: A lot of the time, I'll notice what needs to be done and if I haven't done anything recently or if I feel like it's my turn, then maybe I'll just do it on the spot, or you know plan to in the not-so-distant future. If you weren't that last person to get something, then maybe this time you would get some.}

\section{Why Help is Not Always Offered or Requested}

Although participants expressed a general willingness to help each other complete their tasks when possible, there are some reasons why help is not always requested or offered for all errands. Each member within a household may have specific needs that differ from others, so it may not be easy for participants to ask each other for help. Each participant may want an errand to be done in a particular way, which may make it difficult for others to provide help. These concerns particularly manifested when it came to purchasing food or clothing items. Furthermore, a person might need to make decisions related to an errand in a contextually dependent manner. It would be hard for others to make those decisions for a person.

\footnotetext{
H5-A: I needed [gloves] that were a little bit more agile...It was something where I definitely want to check it out myself, see what the prices are, and try see what the gloves look like on... I can't think of an instance where I would want anyone to buy any clothing item of sorts.
} 
H5-C: You might see fish and go "Oooh!!" And it's just the best selection for what's available that day, so I don't know if other people would be able to make those same decisions that are optimal for me. A lot of the stuff gets to be like that.

Additionally, other people might lack the knowledge and expertise to complete an errand properly. As a result, participants perceive that it is easiest for them to perform the task themselves.

H7-B: The two little ones, they have allergies. So some stuff I have to do it myself [sic]. Some grocery stuff [sic], I buy it myself because they don't know if it has to be gluten-free or free of other things. They don't know so it will take them too long to get the same thing. So for example, when I go to buy flours there are special gluten free ones or special products that I personally know because I use it on a regular basis when I'm cooking. For the rest of the family, we use different products, so they can pick up those items, no problem for us, but not for the two little ones.

Roommates, in particular, expressed not wanting to ask too much of their fellow household members. They describe that it is not their roommate's responsibility to help them perform tasks that they could otherwise do themselves.

\section{H5-A: You definitely ask more of different people in your life depending on what role they occupy or how much love they get from you, you know? I feel more comfortable asking my sister to do things than some guy in class, or you know the people I live with. I have good relationships with them and I'd like to maintain that.}

Often, the amount of effort that goes into performing an errand is a factor that the participants also expressed taking into consideration before asking others to help. Participants noted that some tasks were too lightweight to ask others to do; in those instances, those were errands that they could and should do very easily themselves:

\section{H3-A: it's just mailing in a letter, so I didn't really ask.}

At the same time, participants were also concerned with asking for help when an errand involved what they perceived as possibly a large amount of inconvenience to others. They feared not being able to return the favor in an adequate manner:

H5-B: If I didn't think it was fair or I couldn't compensate them well enough... like if it's something really big or if it's exceptionally far... it's not their thing to do. I wouldn't make them do something that's out of balance in terms of time, money, distance or effort. I wouldn't ask them, because I don't know if I would be able to reciprocate that.

The type of errand and reimbursement tracking would sometimes affect whether a household member would ask for help. If the errand was of a personal nature it might be embarrassing or inappropriate to ask for assistance, and the effort involved in maintaining 'who owes who' was more effortful/troublesome than performing the errand:
H4-C: I won't ask to help with an errand if it's a personal item I know I need to reimburse them. If it's a community item and I don't need to reimburse them and its communal then I'd verbalize what I need.

The dependability of a household member influenced who a participant was willing to ask for assistance:

H6-B: The reason I won't ask my brother to do anything is because he will say, "Give me five minutes." I'll be sitting there waiting and I'll say, "Five minutes is done," and then he'll go, "Wait five more minutes." We'd be waiting and then time will go by, and my dad will yell at me. We'd all be yelled at, and my brother will still be sitting there. So instead, I'll just do it myself. When I come back, he'll still be sitting there.

If a person is unreliable or sometimes unwilling to help, then participants were less likely to ask that person for help or offer them assistance in the future:

H6-B: If I did something for them and then I want them to do something for me and they don't, and they ask me to help them [again later on], I'll say, "No, I won't help you."

Finally, participants reported that sometimes they preferred to perform their own errands because it is an excuse for personal time.

H5-C: I don't know about you guys, but I like the act of going.

H5-A: Uh-huh. Yeah. I definitely use shopping as an excuse to get out that day because I don't have anything else to do other than like homework... it's a way to relax and so I use that as an excuse a lot of the time... to kinda get out of the house too... to take a break from studying, to take a walk, get air.

H5-C: It's kind of social too because there are other people on the street that you can come into eye contact with.

\section{DESIGN OPPORTUNITIES}

In the final interview, we asked participants to reflect on the practices used for completing errands within their household and possible opportunities for addressing the challenges that they faced. Participants disclosed how their current methods for sharing errands are problematic, but they also suggested information services that they believe can help in the performance of errands. Three primary themes emerged during the final interview that should be considered in designing tools to support errands: provide the ability to share location information; allow for sharing of a private and communal errands list; and recognize that an errand can have particularities that need to be expressed to the person(s) who will eventually perform the errand. These three themes present opportunities to improve the performance of an errand and errand sharing within a household.

Participants discussed that location and availability are key factors in determining if they would request help to complete an errand and when they would offer to help perform an errand. Although many of the participants disclosed using a variety of communication methods to share their location (e.g., SMS, Facebook Places), few actively used these tools to communicate their location for the purpose of coordinating errands. Instead, participants discussed an opportunity for a 
collaborative errand service that supports an explicit push model for location sharing and errand availability would support the participants' current behaviors and reduce the overhead of requesting and negotiating availability. In particular, such an explicit push model would help the user maintain her privacy by ensuring that their location and availability are only disclosed when they choose:

\section{H5-B: I'm not into the idea of having people be able to track my movements during the day, but I do like the idea of if I want to share the information, I can.... I just like the privacy.}

In sharing one's location, participants alluded to a shared errand list that could lower the barrier to help others. Participant H6-B commented that "if I could see other people's errands and I could do it, then I would do it." A shared errand list also meets two design requirements discussed by the participants. First, it enables errand sharing to be implicitly initiated by the person who needs help; as participant H3-A explains "the input should be from the person who wants the thing, instead of the person who might be able to get the thing. " In turn, the ability to share and track the errands of other household members while mobile could foster more opportunistic collaboration. The shared errand list allows users to determine when to push their location to others to offer their help, if it is still needed. When inputting an errand, the user could manually annotate the places she knows where her errand can be performed, or more sophisticated techniques could be used to automatically determine opportunistic places to perform the errand.

\section{H5-A: Let's say in the next month you know you're going to need a few different things -- sort of long-term errands... so then you put in your database or whatever it is all the items that you need or needed... say you needed it at [large discount department store], and then someone happens to be at [hardware store] and can possibly get it there and then when a person is at such and such a store, they can see it on their phones... a list of things people desire and then they can check in to the group.}

Participants also discussed that how an errand is performed and a person's expertise (or ability) to perform the errand strongly influence who they will ask for assistance. For example, participant H7-B discussed her hesitations in asking her family with performing food related errands because they might pick the "wrong" item.

\section{H7-B: My kids are allergic, so I have to go and be sure what to get. I can easily get vegetable and fruits, but not the other stuff, because I have to see if it has colorants, if it has gluten, if it has anything, so... \\ H7-A: It's just that I can't remember. And even if she tried to tell me over the phone, I'd see 20 different things and I'll be like, is it this one? Is it this one? So, yeah, it'll be a hell of a lot faster if she did it.}

Thus, participants expressed a desire to have capabilities that would enable them to document how to perform an errand so that others will be able to help when possible.
Finally, the opportunities described could greatly increase collaboration, but the roommate participants in our study still felt that a deterrent from sharing errands was a convenient method to track spent resources and ensure that reciprocity is maintained within the household. Roommates (more so than family members) felt conscious about the time, money and effort spent by other household members on behalf of their personal errands to maintain reciprocity, and ensure that they were not taking advantage of particular relationships:

\section{H5-B: I guess the biggest problem is how to keep track of how much the items cost because it's a lot of punching in the numbers...I know they have those pixelated bar code things where you can take a picture of it and maybe that can scan the receipt of you want to get super integrated with all those different options...that's really a really personal thing because money can be a very serious issue}

In order to promote awareness of the time, money and effort spent, tools could provide better methods to track and maintain balance between household members.

The design opportunities identified by our participants show areas of exploration to promote further household errand collaboration. Many of these themes can be addressed through mobile applications that help facilitate the sharing of errands and communication among household members. In future work we plan to build and evaluate the usefulness of these tools in promoting errands within households.

\section{CONCLUSION \& FUTURE WORK}

In this work, we conducted a 3-week diary study with 8 households to examine how family members and roommates share and accomplish tasks both individually and together. We report the types of errands that family members and roommates share with each other, their motivations for offering and requesting help to complete their errands, and the methods for doing so. We uncover that participants would often ask for help based on the location, availability, or capability of other household members.

There are many opportunities to help improve cooperative errands within households of family members and roommates. Based on our observations and interviews with participants we discovered several design opportunities to help facilitate and encourage cooperative errands. Current methods for communicating and sharing errands could be improved by enabling easier sharing of errands, displaying whereabouts of other household members, and communicating the availability of household members to assist with errands. These themes provide the foundation and direction to build mobile tools and evaluate their effectiveness in expressing and communicating errands within households.

\section{REFERENCES}

1. Beech, S., Geelhoed, E., Murphy, R., Parker, J., Sellen, A., Shaw, K. Lifestyles of working parents: Implications and opportunities for new technologies, HP Tech report HPL2003-88 (R.1), 2004. 
2. Bellotti, V., Dalal, B., Good, N., Flynn, P., Bobrow, D., Ducheneaut, N. What a to-do: studies of task management toward the design of a personal task list manager. Proc. CHI 2004, ACM Press (2004), 735-742.

3. Bellotti, V., Smith, I. Informing the Design of an Information Management System with Interactive Fieldwork. Proc. DIS 2000, ACM Press (2000), 227- 237.

4. Bentley, F., Metcalf, C.J. Location and activity sharing in everyday mobile communication. Ext. Abstracts CHI 2008, ACM Press (2008), 2453-2462.

5. Bergman, O., Boardman, R., Gwizdka, J., Jones, W. Personal Information Management. Proc. CHI 2004, ACM Press (2004), 1598-1599.

6. Beyer, H., Holtzblatt, K. Contextual Design: Defining Customer-Centered Systems. Morgan Kaufmann, 1992.

7. Boardman, R., Sasse, M. Stuff Goes into the Computer and Doesn't Come Out, A cross-tool Study of Personal Information Management. Proc. CHI 2004, ACM Press (2004), 583-590.

8. Brown, B.A.T., Taylor, A.S., Izadi, S., Sellen, A., Kaye, J., Eardley, R. Locating Family Values: A Field Trial of the Whereabouts Clock. Proc. Ubicomp 2007, Springer-Verlag (2007), 354-371.

9. Brush, A.J.B., Meyers, B.R., Tan, D.S., Czerwinski, M. Understanding memory triggers for task tracking. Proc. CHI 2007, ACM Press (2007), 947-950.

10. Brush, A.J.B., Turner, T.C. A survey of personal and household scheduling. Proc. GROUP 2005, ACM Press (2005), 330-331.

11. Crabtree, A., Rodden, T. Domestic routines and design for the home. Computer Supported Cooperative Work 13, 2 (2004), 191-220.

12. Davidoff, S., Zimmerman, J., Dey, A.K. How routine learners can support family coordination. Proc. CHI 2010, ACM Press (2010), 2461-2470.

13. Dearman, D., Kellar, M., Truong, K.N. An examination of daily information needs and sharing opportunities. Proc. CSCW 2008, ACM Press (2008), 679-688.

14. Dey, A., Abowd. G. CybreMinder: A context-aware system for supporting reminders. Proc. HUC 2000, Springer-Verlag (2000), 172-186.

15. Elliot, K., Neustaedter, C., Greenberg, S. StickySpots: using location to embed technology in the social practices of the home. Proc. TEI 2007, ACM Press (2007), 79-86.

16. Fiese, B.H., Tomcho, T.J., Douglas, M., Josephs, K., Poltrock, S., Baker, T. A review of 50 years of research on naturally occurring family routines and rituals: Cause for celebration? Journal of Family Psychology 16, 4, (2002), 381-390.

17. Jung, Y., Persson, P., Blom, J. Dede: Design and Evaluation of a Context-Enhanced Mobile Messaging System. Proc. CHI 2005, ACM Press (2005), 351-360.

18. Kim, S., Kim, M., Park, S., Jin, Y., Choi, W. Gate Reminder: A Design Case of a Smart Reminder. Proc. DIS 2004, ACM Press (2004), 81-90.
19. Klepis, N., Nelson, W., Ott, W., Robinson, J., Tsang, A., Switzer, P., Behar, J., Hern, S., Engelmann, W. The National Human Activity Pattern Survey. Journal of Exposure Analysis and Environmental Epidemiology, 11, 3 (2001), 231-252.

20. Lansdale, M. The Psychology of Information Management. Applied Ergonomics 19, (1988), 55-66.

21. Lindley, S.E., Harper, R.H.R., Sellen, A. Designing a technological playground: a field study of the emergence of play in household messaging. Proc. CHI 2010, ACM Press (2010), 2351-2360.

22. Ludford, P.J., Frankowski, D., Reily, K., Wilms, K., Terveen, L.G. Because I carry my cell phone anyway: functional location-based reminder applications. Proc. CHI 2006, ACM Press (2006), 889-898.

23. Marmasse, N., Schmandt, C. Location-Aware Information Delivery with comMotion. Proc. HUC 2000, SpringerVerlag (2000), 64-73.

24. Neustaedter, C., Brush, A.J.B. "LINC-ing" the family: the participatory design of an inkable family calendar. Proc. CHI 2006, ACM Press (2006), 141-150.

25. Neustaedter, C., Brush, A.J.B., Greenberg, S. The calendar is crucial: Coordination and awareness through the family calendar. ACM Transactions on Computer-Human Interaction 16, 2 (2009), 1-48.

26. O'Hara, K., Harper, R.H.R., Unger, A., Wilkes, J. Sharpe, B., Jansen, M. TxtBoard: from text-to-person to text-tohome. Ext. Abstracts CHI 2005, ACM Press (2005), 17051708.

27. Remember The Milk: Online to do list and task management. http://www.rememberthemilk.com/ Last accessed June 3, 2011.

28. Sellen, A., Harper, R.H.R., Eardley, R., Izadi, S., Regan, T., Taylor, A.S., Wood, K.R. HomeNote: supporting situated messaging in the home. Proc. CSCW 2006, ACM Press (2006), 383-392.

29. Sohn, T., Li, K.A., Lee, G., Smith, I.A., Scott, J., Griswold, W.G. Place-Its: A Study of Location-Based Reminders on Mobile Phones. Proc. Ubicomp 2005, Springer-Verlag (2005), 232-250.

30. Strauss, A., Corbin, J. Basics of Qualitative Research: Grounded Theory Procedures and Techniques. Sage Publications, 1990.

31. Taylor, A.S., Swan, L. Artful systems in the home. Proc. CHI 2005, ACM Press (2005), 641-650.

32. Taylor, A.S., Swan, L., Eardley, R., Sellen, A., Hodges, S., Wood, K.R. Augmenting refrigerator magnets: why less is sometimes more. Proc. NordiCHI 2006, ACM Press (2006), 115-124.

33. Taylor, A.S., Swan, L. List making in the home. Proc. CSCW 2004, ACM Press (2004), 542-545.

34. Tolmie, P., Pycock, J., Diggins, T., Maclean, A., Karsenty, A. Unremarkable computing. Proc. CHI 2002, ACM Press (2002), 399-406. 